\title{
PENERAPAN MODEL PEMBELAJARAN ROLE PLAYING UNTUK MENINGKATKAN KEMEMPUAN SPEAKING SISWA KELAS XI IPS 3 SMAN 1 MALINAU
}

\section{DOORVINA}

SMAN 1 Malinau

e-mail: vina.amoparentala@gmail.com

\begin{abstract}
ABSTRAK
Salah satu tujuan dari pembelajaran bahasa Inggris adalah siswa dapat melakukan komunikasi secara lisan dan tertulis. Siswa SMAN 1 Malinau khususnya kelas XI IPS 3 memiliki kemampuan bahasa Inggris paling rendah dibandingkan dengan kelas lainnya yang diampu penulis khususnya dalam keterampilan berbicara. Hal ini terlihat dari nilai rata-rata keterampilan berbicara yaitu hanya 60 sedangkan standar rata-rata yang ditetapkan oleh SMAN 1 Malinau untuk keterampilan berbicara adalah 70. Selain itu rata-rata nilai tes praktik yang dicapai oleh kelas XI IPS 3 SMAN 1 Malinau adalah 67 dengan ketuntasan hanya 53\%. Tujuan dari penelitian ini adalah untuk mengetahui apakah kemampuan berbicara dalam bahasa Inggris siswa dan hasil belajar siswa dapat ditingkatkan melalui Model Roleplay. Dimana subjek penelitian adalah Siswa kelas XI IPS 3 SMA Negeri I Malinau Semester I Tahun Ajaran 2021/2022. Penelitian ini menggunakan metode kualitatif deskriptif. Dari hasil observasi dalam pembelajaran Bahasa Inggris ketika menerapkan model pembelajaran role playing, terlihat adanya peningkatan kemampuan berbicara Bahasa Inggris siswa, dimana siswa terlihat lebih semangat dalam berkomunikasi dan lebih lancar dalam menggunakan bahasa inggris, yang berpengaruh terhadap peningkatan hasil belajar siswa yaitu dengan kategori sangat baik mencapai $56 \%$, kategori baik $31 \%$, sedangkan kategori cukup hanya $13 \%$. Sedangkan hasil tes praktik ketika menerapkan model pembelajaran role playing mengalami peningkatan serta diiringi pula meningkatnya kemampuan berbicara bahasa Inggris siswa dengan nilai rata - rata 86,9 sehingga ketuntasan belajar mencapai $95 \%$. Hasil ini menunjukan ketetapan semua indikator telah dicapai, dengan demikian penggunaan model Role Playing dalam pembelajaran Bahasa Inggris dapat meningkatkan kemampuan berbicara Bahasa Inggris siswa kelas XI IPS 3 SMA Negeri 1 Malinau tahun ajaran 2021 / 2022.
\end{abstract}

Kata Kunci: Bahasa Inggris, speaking, role playing

\section{PENDAHULUAN}

Kemampuan berbicara adalah sebuah keterampilan untuk mengungkapkan pendapat atau pikiran dan perasaan kepada orang lain atau kelompok secara lisan, baik ketika berhadapan maupun dalam jarak jauh. Berbicara juga alat untuk mengungkapkan pikiran dalam bentuk tingkah laku sosial. Jadi kemampuan berbicara adalah keterampilan menyusun kalimat-kalimat untuk menampilkan bahasa dalam bentuk komunikasi. Keterampilan berbicara merupakan inti dari proses pembelajaran bahasa di sekolah, karena dengan pembelajaran berbicara siswa dapat berkomunikasi baik di dalam maupun di luar kelas sesuai dengan perkembangan jiwanya (Galda dalam Supriyadi, 2009)

Belajar bahasa pada hakikatnya adalah belajar berkomunikasi, dan komunikasi itu adalah berbicara. Speaking atau berbicara adalah bagian terpenting dalam proses belajar bahasa Inggris. Speaking menjadi salah satu aspek yang harus dikuasai siswa dalam mata pelajaran Bahasa Inggris. Sistem belajar percakapan Bahasa Inggris harus mengutamakan kemampuan komunikasi siswa. Hal ini sejalan dengan pendapat Wilkin dan Maulida dalam Malihah (2010) menyatakan bahwa tujuan pengajaran bahasa Inggris dewasa ini adalah untuk berbicara.

Berdasarkan hasil pengamatan peneliti dan hasil belajar siswa, peneliti menemukan proses pembelajaran yang dilakukan khususnya pada pembelajaran bahasa Inggris pada aspek keterampilan berbicara (speaking) masih belum optimal. 
Lulusan SMA, diharapkan memiliki keterampilan berbicara (speaking) secara aktif. Namun pada kenyataannya masih banyak lulusan SMA yang belum memiliki keterampilan tersebut. Gejala rendahnya keterampilan speaking di tunjukan dengan sebagian besar siswa terlihat masih takut untuk mengemukakan pendapat, tidak terbiasa berbicara di depan kelas, malu bertanya, kurang percaya diri dalam berkomunikasi. Hal ini di sebabkan oleh métode dan proses belajar mengajar yang kurang efektif. Ketidakaktifan ini salah satunya disebabkan karena guru masih menerapkan teacher learning center, dimana guru menjadi pusat pembelajaran sehingga siswa menjadi kurang aktif. hal ini terlihat dari siswa yang kurang berani mengungkapkan pendapat atau ide dalam diskusi kelompok. Diskusi banyak didominasi oleh beberapa siswa sedangkan yang lain tidak berpartisipasi aktif, Untuk itu guru dituntut lebih inovatif dalam proses belajar mengajar, salah satunya dengan menerapkan student learning center, dimana dalam proses belajar mengajar guru hendak nya memberikan kesempatan yang cukup kepada siswa untuk terlibat aktif dalam pembelajaran, karena dengan keaktifan ini siswa dapat lebih memahami, mendalami dari pengalaman yang ia peroleh dengan keaktifannya dalam kegiatan belajar. Kelas XI IPS 3 SMA Negeri 1 Malinau adalah subjek dimana peneliti mengadakan penelitian. Dalam kegiatan pembelajaran Bahasa Inggris, Penulis masih menemukan sebagian siswa yang tidak termotivasi untuk berbicara bahasa Inggris dan kemampuan berbicara Bahasa Inggris siswa masih sangat kurang, kekurangan tersebut di sebabkan dari beberapa faktor, baik dari guru, lingkungan dan juga siswa itu sendiri. Peneliti menemukan permasalah dalam pembelajaran dimana guru hanya berfokus pada buku pelajaran atau buku paket yang ada. Sehingga pembelajaran terkesan monoton, kurang menarik bagi siswa, ketika guru meminta siswa untuk berbicara dalam bahasa Inggris, siswa terlihat ketakutan dan malu. Dan ketika siswa diajak berkomunikasi menggunakan bahasa Inggris, siswa nampak kesulitan dalam menyampaikan pendapat nya, karena siswa tersebut merasa kuatir jika kata - kata yang di ucapkan salah atau bahkan menjadi bahan tertawaan bagi siswa yang lain.

Kita ketahui bahwa dengan adanya pembelajaran interaktif muncul berbagai metode pembelajaran yang dapat memotivasi siswa Salah satunya metode role playing. Role playing adalah model pembelajaran gerak yang didalamnya terdapat tujuan dan aturan yang dibalut dengan unsur senang (Jill Hadfield, 1986). Metode ini dilakukan dengan bermain peran, di mana siswa akan mengucapkan dialog yang telah dipersiapkan sebelumnya atau hasil impovisasi. Cara ini akan memberi kesempatan kepada siswa untuk berlatih pengucapan (pronounciation), berlatih berani berbicara (speaking) berlatih mendengarkan (listening) dari lawan bicara. Dengan bermain peran ini pula siswa dapat memperkaya kosa kata (vocabulary) dalam bahasa Inggris, serta menikmati suasana yang menyenangkan tanpa merasaa terbebani oleh kesalahan pengucapan. Hal ini sejalan dengan pernyataan bahwa pembelajaran menggunakan model role playing akan memberikan pengalaman yang menyenangkan bagi siswa, sehingga membantu dalam pengembangan keterampilan berbahasa (Kristin, 2018; Oktivianto et al., 2018; dalam Dewi 2020)

\section{METODE PENELITIAN}

Penelitian ini menggunakan pendekatan kualitatif, yaitu penelitian yang secara fundamental bergantung pada pengamatan pada manusia. Pengamatan kualitatif mekibatkan pengukuran tingkatan pada suatu ciri tertentu. Oleh karena itu dalam penelitian kualitatif kehadiran peneliti adalah mutlak. Pengumpulan data menggunakan metode observasi dan tes serta dokumen hasil ujian. Pengambilan data terkait penerapan model pembelajaran role playing dilakukan dengan tes praktik berbicara dimana siswa secara berpasanganan memerankan percakapan yang dilakoni oleh siswa sesuai dengan situasi percakapan yang sudah di buat secara berkelompok, sedangkan penilaian kemampuan berbicara siswa dilakukan dengan observasi. Analisis deskriptif digunakan untuk menganalis data perolehan hasil observasi dan tes praktik berbicara. Data observasi yang menggambarkan suasana dan kegiatan 
belajar siswa selama proses pembelajaran dari hasil pengamatan ini dianalisis menggunakan persentase.

Dalam penghitungan nilai rata - rata hasil tes ketika diterapkan pembelajaran model role playing mengalami peningkatan, serta keterampilan berbicara siswa dari segi faktor kebahasaan maupun non kebahasaan mengalami perbaikan. Hasil ujian siswa meningkat dengan nilai standar rata-rata 80 yang arti nya, sudah di atas nilai KKM yaitu 70 .

\section{HASIL DAN PEMBAHASAN}

Siswa Kelas XI IPS 3 berjumlah 32 orang. Kegiatan belajar siswa pada kondisi awal terlihat kurang semangat dan tidak aktif, khususnya dalam pembelajaran keterampilan berbicara. Ketika guru bertanya, hanya sedikit yang menjawab pertanyaan, oleh karena itu guru harus menunjuk siswa untuk menjawab pertanyaan. Ketika guru meminta siswa untuk membaca dialog, sebagian siswa merasa terbebani dan mengalami kesulitan dalam membaca. Hanya beberapa siswa yang menunjukkan sikap bersunguh -sungguh dengan berusaha membacakan dialog. Hasil observasi dalam kegiatan belajar menyatakan siswa dengan motivasi kriteria sedang berjumlah 15 siswa. Siswa dengan berkriteria rendah berbanyak 10 siswa, sedangkan kriteria tinggi hanya 7 siswa.

\section{Hasil}

Hasil observasi dan tes praktik, penilaian kemampuan berbicara bahasa Inggris serta hasil belajar siswa melalui penerapan model role playing yang dilaksanakan guru sebagai peneliti dalam proses pembelajaran bahasa Inggris di kelas XI IPS 3 mengalami peningkatan, baik kemapuan berbicara maupun hasil belajar telah memenuhi standar indikator ketercapaian. Peningkatan kemampuan berbicara bahasa Inggris siswa ditunjukan oleh tabel berikut ini:

Tabel 1. Kemampuan berbicara Bahasa Inggris siswa

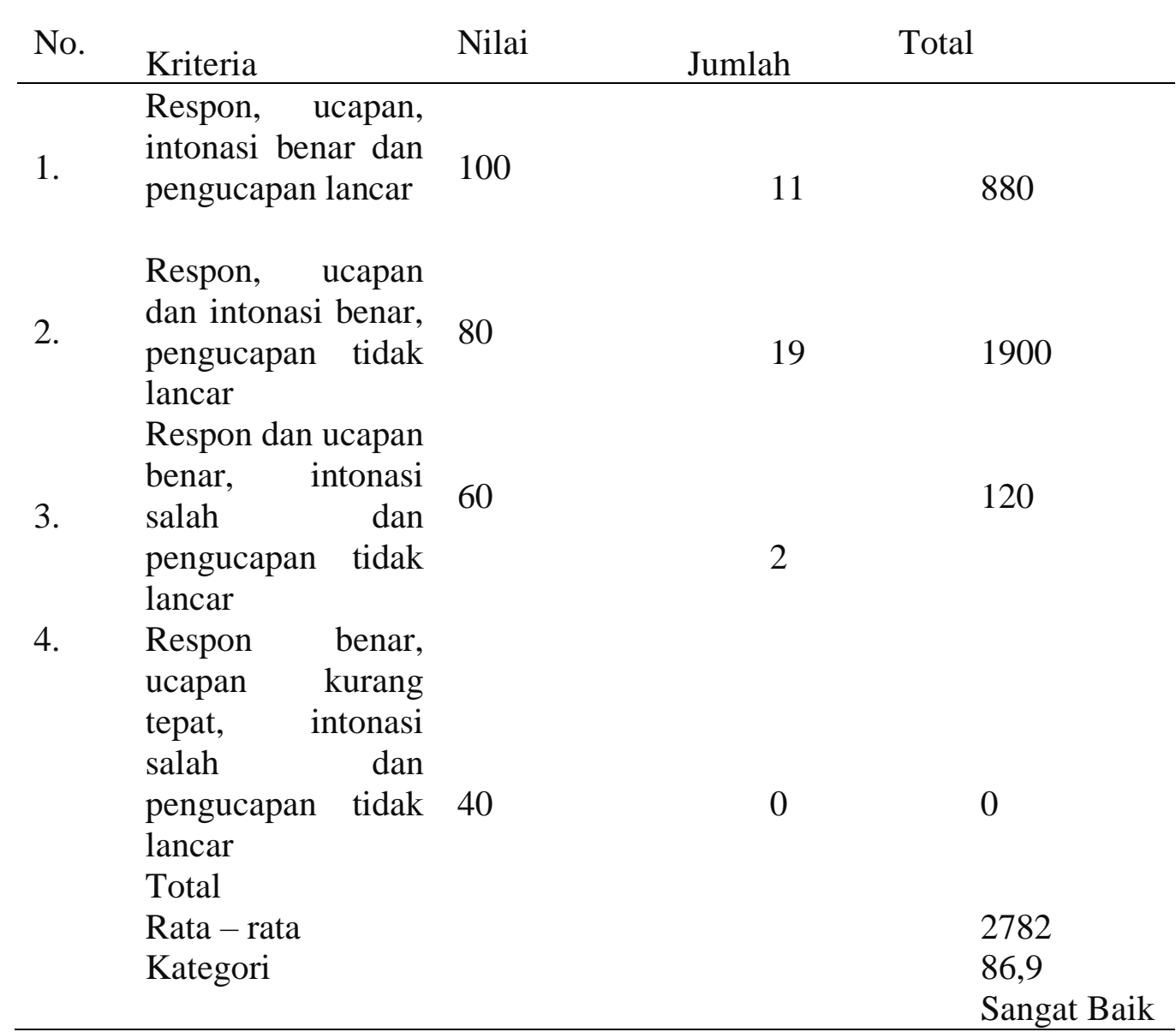


Dari tabel tersebut diketahui bahwa 11 siswa memiliki kemampuan tinggi, 19 siswa memiliki kemampuan sedang, 2 siswa memiliki kemampuan cukup, dan tidak ada yang memiliki kemampuan rendah, sehingga pencapaian rata-rata nilai siswa 86,9. Sebuah pencapaian yang memuaskan, dengan penerapan model role playing telah meningkatkan kemampuan berbicara Bahasa Inggris siswa, yang diikuti juga dengan peningkatan hasil belajar siswa, yang di tunjukan pada tabel berikut:

Tabel 2. Hasil belajar Siswa

\begin{tabular}{|l|l|l|l|l|}
\hline No. & Rentang Penilaian & Kategori & Jumlah siswa & \% \\
\hline 1 & $85-100$ & Sangat Baik & 18 & 56 \\
\hline 2 & $71-84$ & Baik & 10 & 31 \\
\hline 3 & $60-70$ & Cukup & 4 & 13 \\
\hline 4 & $<59$ & Kurang & - & \\
\hline & & & 32 & 100 \\
\hline
\end{tabular}

Dari tabel di atas dapat di lihat hasil belajar siswa dengan kategori sangat baik berjumlah 18 siswa sedangankan hasil belajar siswa dengan kategori baik berjumlah 10 orang siswa, dan hasil belajar siswa dengan kategori cukup hanya 4 siswa. Tidak ada siswa yang mendapatkan hasil belajar dengan kategori kurang. Sehingga ketuntasan hasil belajar siswa mencapai $87 \%$.

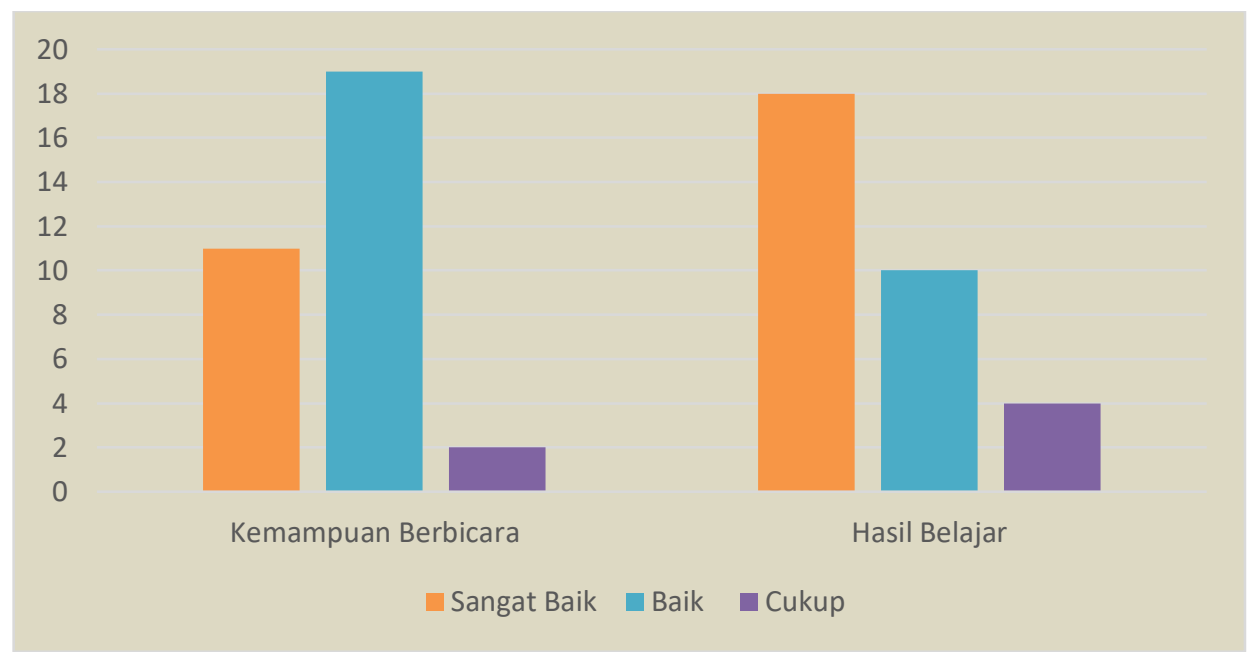

Gambar 1. Grafik Kemampuan Berbicara dan Hasil Belajar siswa

\section{Pembahasan}

Guru sebagai peneliti melaksanakan pembelajaran dengan melakukan observasi kegiatan pembelajaran dan aktivitas siswa di dalam kelas. Selanjutnya guru mengidentifikasi temuan saat melaksanakan observasi. Kelemahan dan keberhasilan pembelajaran dianalisis untuk dipertimbangkan dalam langkah pembelajaran selanjutnya. Metode role playing di pilih sebagai model yang dipertimbangkan oleh guru sebagi langkah untuk membantu siswa dalam meningkatkan kemampuan berbicara bahasa inggris siswa kelas XI IPS 3. Hal tersebut sejalan dengan Pendapat Aliakbari dan Jamaludin, dalam Arifin (2021) yang mengatakan role play effectif dalam membantu siswa untuk meningkatkan keterampilan berbicara mereka.

Observasi data yang menggambarkan suasana dan kegiatan pembelajaran siswa selama proses pembelajaran, serta hasil belajar siswa dianalisis menggunakan persentase yaitu, jumlah score perolehan dibagi jumlah siswa dikali $100 \%$. Sehingga pencapaian hasil belajar siswa ketika di terapkan pembelajaran model role playing, meningkat dengan kategori sangat baik mencapai 56\%, kategori baik 31\%, sedangkan kategori cukup hanya $13 \%$. Suatu hasil pencapaian yang cukup meningkat bagi siswa kelas XI IPS 3, dimana 87\% siswa mencapai nilai di atas KKM (70). Hal ini sejalan dengan pendapat Huda, dalam Nugraha (2014) bahwa role 
playing adalah cara siswa dalam menguasai materi pelajaran dengan pengalaman langsung dimana siswa berperan sebagai tokoh hidup atau benda mati yang melibatkan imajinasi dan penghayatan

Penelitian ini di laksanakan dalam tiga kali pertemuan. Di awal pertemuan, guru memberikan materi dan mengenalkan konsep model pembelajaran role playing kepada siswa, dan siswa terlihat mulai tertarik untuk mengikuti pembelajaran. Pada pertemuan ke dua, siswa di minta untuk membentuk kelompok, lalu setiap kelompok membuat dialog sesuai dengan konsep dan situasi yang telah di siapkan. Kemudian setiap kelompok berlatih memerankan percakapan dengan pengucapan dan intonasi yang benar. Dari hasil observasi yang di lakukan oleh peneliti, siswa terlihat begitu antusias dalam membuat percakapan dan berusaha berlatih mengucapkan kata dan kalimat yang agak sulit untuk diucapkan. Bahkan siswa dengan berani bertanya kepada guru cara mengucapkan kalimat yang benar, sehingga suasana pembelajaran terlihat lebih hidup, suatu hal yang sangat sulit didapatkan dalam pembelajaran model konvensional dimana pusat pembelajaran fokus pada guru dan kurang melibatkan siswa dalam aktivitas pembelajaran. Pada pertemuan ketiga, siswa secara berkelompok tampil memerankan tokoh dalam dialog yang sudah di buat berdasarkan situasi yang sudah di tentukan, terlihat setiap kelompok berusaha menampilkan kemampuannya berbicara dalam bahasa inggris baik dalam pengucapan, intonasi maupun ekspresi yang sesuai dengan dialog yang sudah dibuat. Sementara kelompok lain menyimak tampilan percakapan yang sedang di perankan oleh kelompok lainnya. Sehingga secara tidak langsung terjadi proses pembelajaran menyimak dan menjelaskan yang dilakukan oleh siswa sendiri. Hal tersebut sesuai dengan penelitian Sardiman (2001) yang menyatakan dalam pembelajaran siswa harus aktif. Tanpa adanya aktivitas, maka proses pembelajaran tidak mungkin terjadi.

Penelitian Prasetyo, (2001) menjelaskan bahwa Pembelajaran dengan role playing merupakan suatu aktivitas yang perantik, biasanya ditampilkan oleh sekelompok kecil siswa, bertujuan mengeksploitasi beberapa masalah yang ditemukan untuk melengkapi partisipasi dan pengamat dengan pengalaman belajar yang nantinya dapat meningkatkan pemahaman. Meningkat nya pemahaman siswa terhadap suatu materi sangat di pengaruhi oleh métode pembelajaran yang di gunakan. Metode role play yang melibatkan siswa akan membuat siswa senang belajar karena metode ini memiliki nilai tambah yang dapat memberikan partisipasi kepada seluruh siswa untuk mendapatkan kesempatan yang sama dalam menunjukkan kemampuannya bekerjasama sehingga mencapai suatu hasil yang dapat mengembangkan kemanpuan siswa. Hal ini sesuai dengan penelitian Kasiyati, (2015) yang menegaskan bahwa Role Play adalah simulasi tingkah laku dari orang yang diperankan, yang bertujuan untuk melatih siswa dalam menghadapi situasi yang sebenarnya; melatih praktik berbahasa lisan secara intensif; dan memberikan kesempatan kepada siswa untuk mengembangkan kemampuan berkomunikasi.

\section{KESIMPULAN}

Berdasarkan data hasil observasi pada pembelajaran Bahasa Inggris dengan menggunakan metode role playing dalam meningkatkan kemampuan berbicara Bahasa Inggris siswa, menunjukan hasil dimana siswa telah mau dan mampu berbicara Bahasa Inggris dengan lancar meskipun masih ada beberapa pengucapan yang masih perlu di perbaiki. Sedangkan untuk hasil tes praktik, perolehan nilai siwa dengan kategory sangat baik mencapai 56\%, kategori baik 33\% dan kategory cukup 13\%. nilai rata-rata siswa meningkat pada angka 85 dan kemampuan berbicara bahasa Inggris siswa telah mencapai stándar nilai yang telah ditetapkan yaitu rata-rata minimum 80 di mana siswa telah menyelesaikan ketuntasan belajar dengan nilai rata-rata 86,9 dari standar nilai rata-rata KKM 70 dan ketuntasan belajar 87\%. Dengan demikian, penelitian ini dapat dipetik dua kesimpulan. Penerapan metode role playing dalam pembelajaran Bahasa Inggris dapat meningkatkan kemampuan berbicara bahasa Inggris siswa di Kelas XI IPS 3 SMA Negeri 1 Malinau semester 1 tahun pelajaran 2021/2022. Penerapan 
métode role playing dalam pembelajaran Bahasa Inggris dapat meningkatkan hasil belajar siswa di Kelas XI IPS 3 SMA Negeri 1 Malinau semester 1 tahun pelajaran 2021/2022

\section{DAFTAR PUSTAKA}

Aliakbari, M. \& Jamalvandi, B. (2010). The impact of 'role play' on fostering EFL learners' speaking ability: A task-based approach. Journal of PanPacific Association of Applied Linguistics, 14(1), 15-29.

Arifin, L Efi. (2021). Application Of Role Playing Techniques In Improving The Speaking Ability Of Students. Indonesian Journal og learning and Instruction, 4(1)

Dewi, K Istri AA (2020). Meningkatkan Keterampilan Berbicara Siswa Melalui Model Hadfield, J. (1986). Harap's Communication Games. Australia : Thomas Nelson and Son Huda, M. (2014). Model-model Pengajaran dan Pembelajaran .Yogyakarta: Pustaka Pelajar.

Kasiyati, (2015) Upaya Peningkata Kemampuan Berbicara dalam Bahasa Inggris dengan menggunakan metode Pembelajaran Role Play Jurnal Ilmu Pendidikan LPMP Kalimantan Timur Volume IX Nomor 1, bulan Juni 2015. Halaman 55-66 ISSN: 18583105

Kristin, F. (2008). Meta-Analisis Pengaruh Model Pembelajaran Role Playing Terhadap Hasil Belajar IPS. Refleksi Edukatika : Jurnal Ilmiah Kependidikan, 8(2)

Malihah, N (2010)The Effectiveness of Speaking Instruction throughTask-Based Language Teaching REGISTER, Vol. 3, No. 1, June 2010

Nugraha, Fitra (2014) Penerapan model Role Playing untuk meningkatkan hasil belajar siswa kelas IV. Universitas Negeri Jakarta. 44JPD: Jurnal Pendidikan DasarP-ISSN 20867433 E-ISSN 2549-5801 DOI: doi.org/10.21009/JPD.010.05

Oktivianto, O. I., Hudaidah, H., \& Alian, A. (2018). Pengaruh Implementasi Model Pembelajaran Role Playing dengan Media Film terhadap Motivasi Belajar Peserta Didik dalam Pelajaran Sejarah Materi Perang Palembang Kelas X di SMA Srijaya Negara Palembang. Jurnal Pendidikan (Teori Dan Praktik), 3(2), 113.

Pembelajaran Role Playing Berbantuan Media Audio visual. Universitas Pendidikan Ganesha, Singaraja, Indonesia. Jurnal Mimbar Ilmu, Vol. 25 No. 3, 2020 P-ISSN: 1829-877X E-ISSN: 2685-9033

Prasetyo. 2001 Role Play sebagai Strategi pembelajaran. Jakarta : Rineka Cipta

Sardiman A.M. 2001. Interaksi Dan Motivasi Belajar Mengajar. Jakarta: Rajawali Press

Supriyadi. (2009) Program Bimbingan untuk Membantu Meningkatkan Kemampuan Berbicara Anak Usia Taman Kanak-Kanak. Tesis. Bandung: FIP UP 